\title{
A bi-national appellation of origin: Pisco in Chile and Peru
}

\author{
Pablo Lacoste ${ }^{1 *}$, Diego Jiménez ${ }^{1}$, Amalia Castro², Bibiana Rendón ${ }^{3}$, and Natalia Soto ${ }^{4}$
}

Pisco is a brandy made from selected grapes, restricted as Appellation of Origin (AO) in 1931 in Chile by executive order number 181 of May 15, and also legally protected by Peru in 1991 by executive resolution of December 12 and executive order 001-91-ICTI/IND of January 16. This AO has given rise to a commercial controversy between producers of both countries, who claim it as their own. This article proposes a new thesis: The AO of pisco is actually bi-national, belonging to Chile as well as to Peru. The reason is that the producers of the two countries contributed to the origin and consolidation of this product. Pisco would not exist without the participation of both of them. Therefore, the two countries have coownership rights since they are co-founders.

Key words: Agroindustry, appellation of origin, grape brandy, wine industry.

\section{INTRODUCTION}

Since 2005 there has been a juridical and commercial controversy between Chile and Peru because of the intellectual property of pisco's appellation of origin (AO) that recognizes grape brandy made from selected grapes ('Quebranta', 'Mollar', 'Black Common', 'Torontel', 'Muscat', 'Albillo' or 'Uvina', in the Peruvian case). Peru cultivates 14000 ha and claims author rights. Its argument is that the port of Pisco, as in the case of Porto (Portugal), was the catalyst of the name of the AO recognized as such by the Marqués de Pombal in the 18th century (Ribeiro de Almeida, 2010). In fact, during the Spanish domination, in the southernmost region of Peru a dynamic brandy industry arose, meant to supply the urban markets of Lima (the great Spanish capital in South America) and the mining markets of Potosí (Brown, 1986; Huertas 2004; Soldi, 2006; Rice, 2011; Huertas, 2012). In this sense, the port of Pisco was the critical point from which the brandy production was shipped, and for that reason the product took up that name (Polvarini, 2003; Huertas, 2012). This port was also used to connect maritime and commercial routes between the Precincts of Arequipa and Arica and the northern area of the Kingdom of Chile, specifically

${ }^{1}$ Universidad de Santiago de Chile (USACH), Facultad de Humanidades, Román Díaz 89, Santiago, Chile.

"Corresponding author (pablo.lacoste@usach.cl).

${ }^{2}$ Universidad Católica Silva Henríquez, Facultad de Educación, General Jofré 462, Santiago, Chile.

${ }^{3}$ Universidad de Chile, Facultad de Filosofía y Humanidades, Av. Ignacio Carrera Pinto1025, Santiago, Chile.

${ }^{4}$ Universidad Nacional de Cuyo, Facultad de Filosofía y Letras, Parque Gral. San Martín 5500, Mendoza, Argentina.

Received: 7 September 2013.

Accepted: 10 November 2013.

doi:10.4067/S0718-58392013000400014 the ports of La Serena and Coquimbo in the 16th and 17th centuries.

In the case of the transportation of agricultural goods by mules, the goods were loaded in the port of La Serena. Then, the mule drivers and cart drivers carried them across the San Francisco Pass, Catamarca, Salta, and Jujuy up to Potosí in the 16th and 17th centuries. This route is known until today as the Inca Road (Figure 1).

At the same time, Chile also became interested in pisco. The same as in Peru, in Chile pisco is a brandy made from selected grapes ('Muscat of Alexandria', 'Muscat of Austria', 'Italia', 'Pink Muscat', 'Pedro Jiménez' or 'Torontel'), and it was defined as AO in 1931. The pisco industry now has about 10000 ha vineyards, distributed among 3000 small growers in the area that became the regions of Atacama and Coquimbo, which produce annually about 36 million liters.

Grape brandy producers in Chile and Peru are currently engaged in a hard commercial and juridical contention at the World Trade Organization and in the courts of different consumer countries. Each one claims its exclusive rights to use the pisco AO with its own arguments (Mitchell and Terry, 2011). It should be noted that the AO is aimed to protect the economic, cultural, social and historical heritage of a community provided a state-level monopoly is prevented (Mitchell and Terry, 2011: p. 521). Likewise, an AO facilitates fair trade between two or more countries in the case of products created by unique processes, and allows the smaller producers to trade in a more equitable way in local and international markets because of their products' special qualities, excluding imitations from the markets. In addition, the AO supports access to export and import quotas that ensure trade sustainability for agricultural products and food items.

After examining the historical background, the present article proposes a new thesis: Pisco is neither exclusively 


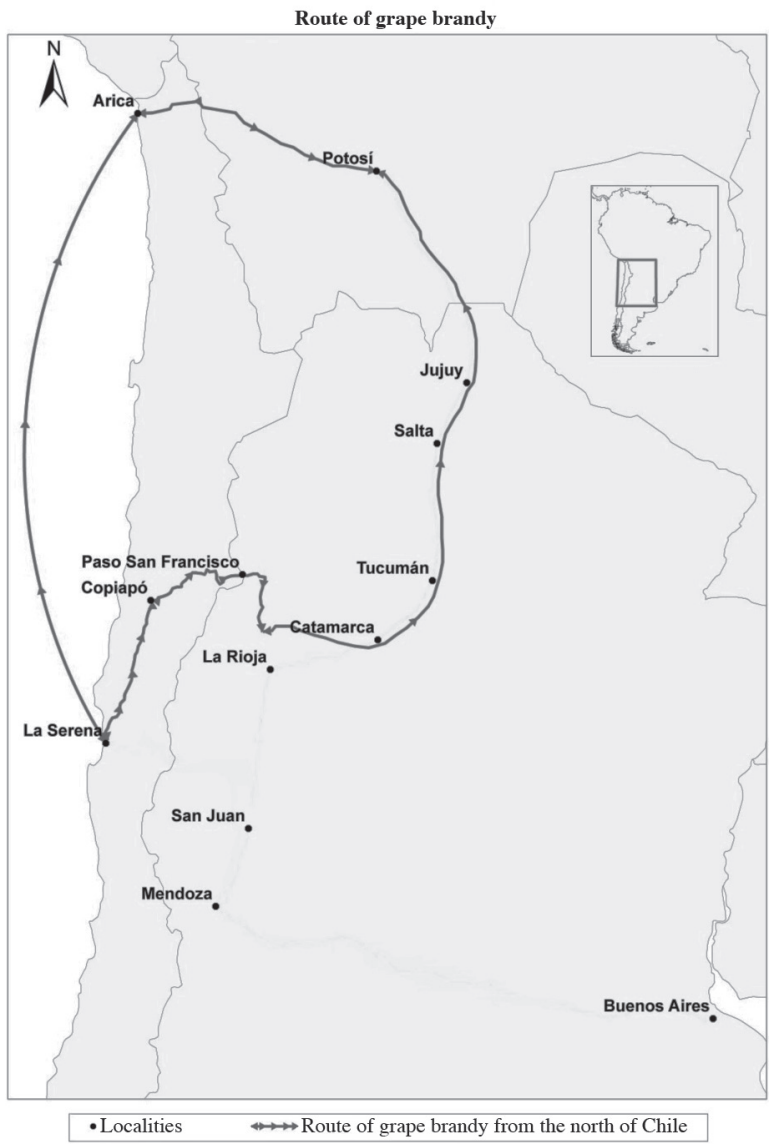

Figure 1. Route of grape brandy during the 16th and 17th centuries. Source: Map made for Bibiana Rendón for Regular FONDECYT Project 1130096.

Peruvian nor solely Chilean, it is a bi-national AO because it was culturally and historically constructed by the producers of the whole region, i.e., of the southernmost 17th-19th century Peru (regions of Ica, Moquegua, Chincha, Arequipa, Tacna, and Arica) and of the northern Regions of Atacama and Coquimbo in Chile. This AO would not exist without the participation of both groups. They contributed to the process of creation, diffusion and prestige of this product in the markets. Both together succeeded in keeping it current through time, from its beginnings by the end of the 16th century to the present.

In order to preserve and promote pisco, both countries have developed numerous initiatives. For example, in 1936 by law 5836, the Chilean government renamed the city of La Unión as Pisco Elqui to reinforce the AO of pisco, while the Peruvian government (after being pressured by grape producers and wine-makers) started successive tax reforms to encourage viticulture and wine-making in the 20th century (Huertas, 2012: p. 170-184). This process is similar to the Spanish AO of Vino de Alicante, most of whose key cultural and historical processes developed from the Visigoths (5th-7th centuries) until the awakening of the Spanish Empire through the union of the Kingdoms of Castile and Aragon (1492) (Fernández, 2005: p. 209214, 229-233). In this context, the economic, cultural, social and political links between those kingdoms and the Kingdom of Valencia developed very positively in the 13th-15th centuries period, when each of these kingdoms was a linguistically, culturally and socially different nation (Fernández, 2005: p. 209-213). The difference between this case and the Chilean-Peruvian case is that while the aforementioned kingdoms united to create the Spanish Empire, Chile and Peru separated into the two states that we know until today, after becoming independent from Spain in the 19th century.

The basis of this new approach is found in history. The Peruvian argument of the local origin of pisco is correct, starting with the strategic role played by the port of Pisco. The expansion of the product took place in the 17th century under Peruvian leadership, and it was demanded by the mining center of Potosí. But to this must be added the fact that the area in which production started in that period was not only southernmost Peru, but also northern Chile. The contribution of this region in the 17 th century was less than that of Peru. However, the correlation of forces was inverted later: the weight of Peru dropped for economic, cultural, political, social and historical reasons, while Chile's importance increased. In this way, a sort of relay race developed in which the two parties contributed to supporting this appellation of origin over time. This phenomenon is the main subject of this paper. Thus, it is exhaustively reviewed in the next paragraphs, focusing the analysis on historical evidence and processes.

\section{DISCUSSION}

\section{Early prominence of Peru}

In the 16th and 17th centuries, Peru developed the most vigorous wine making industry of America. The leadership of Lima, which was called the "City of the Kings", was supported by three pillars: its character as the seat of the Viceroy of Peru (the highest Spanish authority in South America), the local population's density, and the intense economic activity generated around gold mining in Peru and silver in Potosí. Therefore, dynamic markets that required foods and drinks appeared, and this acted as a strong stimulus for growing grapes and making wine and other by-products, among them brandy. An extensive bibliography has reported on the tradition of preparing wine and brandy in Peru in the early colonial period (Brown, 1986; Huertas, 2004; Soldi, 2006; Rice, 2011; Huertas, 2012). The oldest record on brandy in Peru corresponds to the will of Pedro Manuel in 1613 (Huertas, 2012: p. 265-295). In the 17th century there was a large expansion of this activity, whose magnitude was outstanding. For example, in the port of El Callao "in the first decade of the 17th century more than 400000 earthenware containers of wine arrived every year only from Pisco, Ica, and Nasca. Another part of the wine from 
Pisco was shipped south to Arica, from where it was taken up to the mines of Oruro, Porco, and Potosí in caravans of llamas" (Soldi, 2006: p. 57-58).

The Peruvian brandy was usually distilled in large pots and pans. The more sophisticated technology of alembics (apparatus for producing grape brandy by alcoholic distillation) arrived later. From Peru it is stated that they appeared in the 19th century: "in 1826, in the inventory of the Hacienda Galindo of don Félix Cueto (sic), an alembic appears" (Huertas, 2004: p. 53). In the following decade, the same author contributed new data, and stated that Peruvian industry incorporated alembics in the second half of the 18th century (Huertas, 2012: p. 89-90).

Various authors put emphasis in the study of the discovery and first few usages of alembics in Chile and Peru as a key matter to define, defend and sustain their respective assertions about pisco's AO (Huertas, 2004; 2012; Rice, 2011). This is a subject of permanent discussion, not only related to pisco, but to various brandy types, whether or not they are made from grape (Bruman, 1944; Polge, 1956; De las Cuevas, 2003; Huertas, 2004; 2012). In this sense, the creation of the grape brandy known as pisco is deeply linked to the utilization of alembics in the productive process (Huertas 2004; 2012).

Peruvian brandy took the name from Pisco, a small port located $128 \mathrm{~km}$ south of El Callao, because of the use of that port as the commercial throat of pisco between the production zones and the consumption markets. The regional production from Chincha, Ica, and Pisco was carried on mules and carts to that port on the way to $\mathrm{El}$ Callao, to supply Lima, or else to the port of Arica, to then get to Potosí (Huertas, 2012: p. 114).

In the accounting entries of the Spanish tax system, goods that entered or left the interior customs were recorded. In this context, in 1764 data corresponding to peruleras of brandy that arrived to the port of Pisco were recorded. The reiteration of these entries led to the shortening of the phrase "perulera de brandy del puerto de Pisco," which became, from use and habit, "perulera de Pisco" (Polvarini, 2003). Therefore, the name did not refer to the zone of origin of the production, but to the port from which it was shipped.

The Peruvian wine industry reached its peak in the 17th century, and then started decaying, a situation that extended through the 18th, 19th, and 20th centuries. The decline of Peruvian grape brandy had multiple causes, including natural disasters (volcanic eruptions, earthquakes), the substitution of the cultivated grape areas by cotton, and the substitution of grape brandy by sugar brandy, among others. The activity's recovery began by the middle of the 20th century (Huertas, 2012: p. 207).

\section{Chile's contribution}

Pisco's AO in Chile covers an extensive region, limited by Copiapó in the north and Illapel, $500 \mathrm{~km}$ to the south. It is a relatively homogeneous geographical unit, distinguished by its arid climate and oasis economy. The population is concentrated in the small productive valleys of Copiapó, Huasco, Elqui, Limarí, and Choapa. This region was economically, culturally and socially integrated during three centuries because of its main sociopolitical pole, the city of La Serena (founded in 1546), which acted as a leader due to its early foundation. The city council of La Serena was the role model of the local elite; it distributed land and Indian land grants; it provided plants, animals, provisions. La Serena was also the city where political, regulatory and commercial decisions were made (Amunátegui, 1928: p. 22; Sayago, 1973: p. 60). The leadership of La Serena meant new progress possibilities for the north region of Chile, by means of a more integrated space with shared characteristics that appeared due to the coherent actions of the local elite.

The Copiapó Valley was a good example of the process that the remaining valleys in this region went through (in the sense of their gradual colonization), particularly for agricultural and wine-making activities. It was formally incorporated by Pedro de Valdivia in a solemn ceremony in 1540, and a fort was built afterwards (Sayago, 1973: p. 46, 64). Later, Francisco de Aguirre settled there, and he planted the first vineyards in 1549, together with fruit trees, warehouses and a mill (Sayago, 1973: p. 73), driving the community and marking the presence of vine arbors in the city by 1561 (Sayago, 1973: p. 84).

Francisco de Aguirre's house, land, vineyard, and cellar were delivered in April 1578, before the notary of La Serena, to Mrs. Bernarda Aguirre. Later, these assets, estimated at \$4000 (Sayago, 1973: p. 101), went into the hands of the Marqués de Piedra Blanca, Huana y Huanilla. Other grape growing enterprises appeared in Copiapó, and were added to the cattle raising and mining activities, formalizing the founding of the city, originally called San Francisco de la Selva (1744).

The rest of the region underwent a process that paralleled that of Copiapó, with a spread out population settling in the fertile valleys. Not until the 18th century did formal cities like Huasco (1749), Illapel (1754), Combarbalá (1789), and Vallenar (1789) appear. The new cities and small towns meant an important institutional support to facilitate the consolidation of northern Chile's productive enterprises, particularly the brandy industry, as will be discussed in the next sections of this paper.

In a first stage, the region had an important strategic character, allowing the first colonists to take the first round trips to Peru. In that period, Copiapó and La Serena were the articulating hinges of Chile's Spaniards with those of Peru. However, shortly the local elite of the Kingdom of Chile concentrated in its southern region, projecting the conquest of the Araucanía and the Central Valley as a food supply center for the whole Kingdom. As the urban and suburban zones of Santiago were cultivated, it stopped making sense to get supplies from La Serena, located $500 \mathrm{~km}$ to the north. The fertility of the Central Valley 
represented a challenge to the communities of La Serena and Copiapó: Where should they place their surplus? This was the origin of the turn of production in the north of Chile toward the Peruvian markets, a trend that got faster after the appearance of mining in Potosí.

The demand from this mining center was very powerful. The population of Potosí considered itself a "universal consumer of the fruits of the Earth" (Huertas, 2012: p. 146) attracting resources from an extensive region, even from the pampa of the River Plate. Therefore, Chile's economy underwent a deep change in its insertion form within the Spanish Empire, from being one of tough mining producers to one of foods and drinks suppliers.

A strong stimulus for the production of wine and brandy took place in the whole region within this process. The wine producers in the north of the Kingdom of Chile participated actively in this trade, even generating related activities like the development of pastures meant to supply the caravans of loaded mules that travelled to Potosí (Sayago, 1973: p. 109).

The consolidation of the grapes, wine and brandy culture in the north of the Kingdom of Chile took place in the 17 th century, in the region between Copiapó and Illapel, with La Serena as its center. Many wine-related enterprises appeared there, with vineyards having from 2000 to 10000 stocks, their cellars with winepresses and containers, and their centers for producing brandy with pans and alembics. In the 17th century the presence of the alembic was consolidated in the north of the Kingdom of Chile, where alembics were also manufactured and exported to other producer regions, mostly to the province of Cuyo. Since the end of the 17th century the wine-makers of San Juan got alembics and other copper implements manufactured in Coquimbo (Rivera, 2007: p. 144-148). The appearance of alembics so early in the Kingdom of Chile is quite outstanding: they showed up in the 17th century, while in Peru they appeared only in the second half of the 18th century (Huertas, 2012: p. 90).

The examples that have been mentioned allow understanding the general functioning of the system. From Copiapó to the Limarí and Elqui valleys a set of plots and farms were established which, among other activities, grew grapes, made wine, and distilled brandy. In this way a production system meant to supply first the internal market and then the exports was established.

\section{The Pisco producing zone of Chile and its early bond with the Peruvian markets}

The growth of brandy production in northern Chile was part of a larger process marked by the close social, political, cultural and economic relations that the north of the Kingdom of Chile had with southernmost Peru.

Among the authorities of La Serena related with Peru, Perafán de Ribera y Mendoza, born in the port of Pisco (1668), and chief magistrate of La Serena from 1695 to 1697, should be mentioned. On the other hand, Gabriel de Fuica Ladrón de Segarra left his post as mayor of La Serena because he had to travel to Peru, where his father had died (1697). Mayor Domingo Esquivel y Rojas and alderman Juan Marticorena also left their posts because they travelled to Peru. Some families distributed their members between La Serena and Peru, to strengthen their business and professional activities, as in the case of the Egañas. Don Basilio Egaña, a Spanish merchant, settled in La Serena, where he established a well-known business concern and became related with the local political elite (he was guarantor of chief magistrate Diego Montero Carvajal y Cortés in 1707). Three of his sons settled in Peru, where his grandson, Chilean statesman Mariano Egaña, was born (1768). The comings and goings of the Egaña family members between La Serena and Peru marked a trend that included other political and economic activity leaders in the 17th and 18th centuries.

The familiarity of the governors of La Serena with the Peruvian space was important because they were, in turn, protagonists of the local wine-making activity. When grape collection time came, they had to ask permission to leave their public functions and look after the harvest. "Most of the chapter members were farmers and some had their farms away from the city. This was a great inconvenience, but the small number of respectable neighbors made it compulsory to designate them, even though they often needed to leave their functions" (Amunátegui, 1928: p. 114).

During the last years of the 17th and the early years of the 18th centuries the food demand from Peru caused a supply crisis in La Serena. For example, in 1693 a ship arrived to get wheat "due to the extreme need for that product that the City of the Kings was suffering." (Amunátegui, 1928: p. 40). A buying stream was generated that surpassed the region's production capacity. The city council had to take measures to regulate the situation: it set a cargo quota for ships and established a blockade of $10 \%$ of the local production to guarantee supply. In that regard the decision was made of sending alderman Lucas Arquero Ortiz to the Elqui and Limarí Valleys, to get that flour and take it to La Serena to be sold to the bakers to ensure the supply. At one time the city council went to the extreme of "authorizing the chief magistrate to remove by force from the ships the amount of wheat that would be needed." (Minutes of the City Council of La Serena, January 14, 1699). This situation went on for more than a century, at least until 1771 (Amunátegui, 1928: p. 148).

The cited examples are sufficient to show the close political, social, commercial and cultural bonds between the northern part of the Kingdom of Chile and the south of Peru. The center of the Viceroyalty was a role model for the modest oases south of Copiapó, and it modeled, to a large extent, the way of thinking of those simple settlements of peasants. This situation was felt in various planes of productive life, including the world of grapes, wine and brandy. 
Among the protagonists of the production of Chilean brandy in the 17th century, Pedro Cortés y Monrroy, Marqués de Piedra Blanca, Huana y Huanilla (16511717), had a very special place. He was born in La Serena, stood out in the military, and in politics, commerce and economic production. He was chief magistrate, mayor, city council alderman, and attorney. From his family he received a set of particularly valuable lands, including Monterrey, 800 cuadras in Huana (south of Ovalle), the land grant of Atelcura (north of the Choapa), and 2000 additional cuadras close to the previous ones. In these lands he set up the farms that were the basis of his nobility title of "Marqués de Piedra Blanca, Huana y Huanilla" (1697).

The wine industry in general and the production of brandy in particular are activities associated with small properties, work culture, and social mobility. From this perspective, the presence of a noble who owned large inherited lands seems to be an anomaly. However, in this case the reinforcing effect of the Marqués de Piedra Blanca on the economy of the north of Chile in general, and on the industry of brandy in particular, was outstanding. Through his political and commercial networks he succeeded in expanding his local production activity span, projecting it more easily toward the foreign markets and achieving the long term consolidation of the activity. In this respect, the Marquis played a fundamental role in the construction of bonds between the regional economy and Peru, a matter that would have profound implications in the future identity of Chilean pisco.

The economic activities of the Marqués de Piedra Blanca were characterized by diversification. In his farms there were mining, agricultural, cattle raising, and agroindustrial enterprises. He grew wheat, fruit orchards, and vineyards. He had mills to manufacture flour and make bread; cellars for making wine and brandy; tanning, blacksmith and carpentry workshops. He also raised cattle that were used to obtain various by-products. In spite of his nobility title, the Marquis actually operated as a bourgeois entrepreneur, alert to lead the industrial and commercial activities of the region.

Placing his products in the Peruvian market was one of the objectives of Don Pedro. One of the best known economic operations of the whole period took place in 1680, when he travelled carrying a load of cordovan leather and carved copper (Amunátegui, 1928: p. 124). He also sold real estate in the Peruvian market, a more risky and complicated kind of activity. The need to travel more than $2000 \mathrm{~km}$, the uncertainty of the means of transport, the lack of road safety, and the lack of an infrastructure, contributed to complicate these procedures. However, the Marquis succeeded in completing this successfully by his own means. When he wrote his will, he highlighted the methods and resources by which he got his properties and increased his assets, among which the Indians who worked in the copper mines, tanneries and farms prevailed.
The growth of Marqués de Piedra Blanca's productive potential called the attention of Peruvian merchants to supply their needs for brandy and satisfy the always high demand of the local market. This was the case of Captain Manuel Vázquez de Osorio. A peninsular Spaniard living in Peru, Don Manuel was an outstanding figure in Arica, where he held the office of chief magistrate (1722-1723). This was an important port in the region's commercial circuits, because it served to supply the mining market of Potosí with goods coming from Peru. With the decline of the Peruvian brandy industry came, the need to get new suppliers, and Don Manuel made the decision to get them from the north of Chile. He contacted Don Agustín Niño de Zepeda, mayor of La Serena (1702-1703), and told him what he wanted. Don Agustín agreed to help him, on the condition of becoming part of the business. The next step was to contact the Marqués de Piedra Blanca and General Lucas Arquero Ortiz, who Don Agustín knew very well, because he had also occupied high posts (he had been high magistrate of La Serena and member of the city council several times). Later, the business was completed and the contract was signed (January 12,1711). What is important to point out is that this agreement took place within the framework of close commercial, political and social relations that existed between the north of Chile and the south of Peru during the Spanish colonial period. These economic activities were not devoid of conflicts, and these kinds of situations occurred among various social sectors, including some native groups, in the north of Chile as well as in Peru.

When referring to the administration of the family property, the Marquis mentioned the importance of the negotiations with the Indians of Huasco, as well as with others in the so-called "encomienda de Pisco" ("Pisco land grant"), because they were extremely demanding from the economic standpoint and of high complexity in their treatment. The Indians of the Pisco land grant were located around the Pisco valley (Huertas, 2012: p. 127). The contact of the Marqués de Piedra Blanca with the Indians of the Pisco land grant (mentioned explicitly in his will) is important for our history because it shows a proximity link between the main producer of brandy in the north of Chile at that time with the Peruvian world, the Pisco region, and the indigenous community of that place. If Don Pedro had disputes with the Indians of the Pisco land grant, it is because he interacted with it; he transferred goods through that place, carried out operations, generated activities, and interacted with a region and a culture.

\section{CONCLUSIONS}

This paper allows the current conflict between Chile and Peru for the intellectual property of the appellation of origin (AO) pisco to be demystified. This conflict is innocuous because pisco, as a prestigious product in 
the markets, would not exist if it had not counted on the participation of producers from a larger region that involved the south of Peru as well as the north of Chile.

In the first century of its history, the contribution of Peru was greater, particularly due to the protagonism of the port of Pisco as a great catalyst of production, a process that was reflected in the name that was given to the regional brandy. At that time the producers of the north of Chile had a secondary role, but they also participated in the process: in the 17th century the production of grape brandy was consolidated in an extensive region that stretched from Copiapó to Illapel. The industry reached some high points such as, for example, the early incorporation of alembics one century before Peru.

It is important to point out that in the 17 th and 18 th centuries there were close economic, social, cultural and political links between the north of Chile and Peru. There was a constant circulation of merchants, producers and governors between both regions. The analysis of the mayors and chief magistrates of La Serena shows these links. Many of them had to travel back and forth to Peru as part of their personal, professional, commercial and political life. These links are also explained by the juridical conditions of that time: both locations belonged to the Viceroyalty of Peru and to the Spanish Empire. Within this space a relatively integrated brandy industry appeared in which the whole macro region was coordinated to supply the main market of Potosí through the port of Arica or the roads on land. This led to the configuration of a set of commercial routes that facilitated the population of the macro region, and therefore expanded considerably the dynamics of its economy, based considerably on drinks and foods, among which brandy played a fundamental role.

In the 18th century the brandy industry of Peru started declining. The main reasons were natural catastrophes (volcanic eruptions, earthquakes); the replacement of grape brandy with sugarcane brandy because of its lower cost, and the replacement of vineyards with cotton plantations because of the English industrial revolution, among other reasons.

Northern Chile did not undergo these changes; sugarcane could not be grown because of the climate; cotton plantations did not succeed; and furthermore, the earthquakes did not have an equivalent impact. Therefore, the Chilean brandy industry remained alive and began replacing the Peruvian. The first exports of brandy from the north of Chile to the Peruvian markets took place at the beginning of the 18 th century.

In the 19th and part of the 20th centuries the Chilean industry kept alive the tradition of grape brandy and of the Pisco AO, defined as such by president Ibáñez in 1931. Then, since 1950, Peru regained its old interest in this product, and again started making it and promoting it. Toward the end of the 20th century both countries have evened up in terms of the size of their respective industries, and have started commercial and juridical battles for the intellectual property rights. In the light of this historical background, it seems more adequate to recognize pisco as a bi-national AO.

\section{ACKNOWLEDGEMENTS}

The present article was prepared with the financial support of the Comisión Nacional de Investigación Científica y Tecnológica (CONICYT) through Regular FONDECYT Project COD 1130096 on "Denominaciones de origen e identidad de vinos y agroalimentos en Chile (18701950)" ("Appellations of Origin and identity of wines and agricultural food in Chile (1870-1950)").

\section{LITERATURE CITED}

Amunátegui, D. 1928. El cabildo de La Serena 1678-1800. Universo, Santiago de Chile, Chile.

Brown, K. W. 1986. Bourbons and Brandy: Imperial Reform in Eighteen-Century Arequipa. University of New Mexico Press, Albuquerque, New Mexico, USA.

Bruman, H. 1944. The Asiatic Origin of the Huichol Still. Geographical Review 34(3):418-427.

De las Cuevas, J. 2003. Historia apasionada del Brandy de Jerez. Ediciones Geribel, Sevilla, Andalucía, España.

Fernández, S. 2005. La cultura del vino en la construcción de la premeseta murciana y alicantina: algunos modelos de desarrollo local en torno a la simbología del vino (Jumilla y Yecla, Monóver y Villena). Revista Murciana de Antropología 12:209-234.

Huertas, L. 2004. Historia de la producción de vinos y piscos en el Perú. Universum 19(2):44-61.

Huertas, L. 2012. Cronología de la producción del vino y del pisco (Perú 1548-2010). Editorial Universitaria, Lima, Perú.

Mitchell, J. T., and W. C. Terry. 2011. Contesting Pisco: Chile, Peru and the politics of trade. The Geographical Review 101(4):518535.

Polge, H. 1956. L'Ouitillage viticole traditionnel de L'Armagnac (I). Arts et traditions populaires 4(2):97-112.

Polvarini, A. 2003. Hacienda de vid y producción de brandy en el Perú del siglo XVIII. LI Congreso Internacional de Americanistas, Santiago de Chile, Chile. 14 al 18 de julio.

Ribeiro de Almeida, A. 2010. A autonomia jurídica da deniminação de Origem. Uma perspectiva transnacional. Uma garantia de qualidade. Coimbra Editoria, Porto, Portugal.

Rice, P. 2011. Vintage Moquegua. History, wine and archaeology on a colonial Peruvian periphery. University of Texas Press, Austin, Texas, USA

Rivera, A. 2007. La infraestructura para la elaboración de caldos: bodegas y lagares en San Juan de la Frontera (s. XVII-XVIII). Universum 22:136-150.

Sayago, C M. 1973. Historia de Copiapó. 2a ed. Editorial Francisco de Aguirre, Santiago de Chile.

Soldi, A. M. 2006. La vid y el vino en la costa central del Perú, siglos XVI y XVII. Universum 21:42-61. 